\title{
Upon oxidative stress, the antiapoptotic Hsp60/procaspase-3 complex persists in mucoepidermoid carcinoma cells
}

\author{
C. Campanella, ${ }^{1}$ F. Bucchieri, ${ }^{1}$ N.M. Ardizzone, ${ }^{1}$ A. Marino Gammazza, ${ }^{1}$ A. Montalbano, ${ }^{1}$ \\ A. Ribbene, ${ }^{1}$ V. Di Felice, ${ }^{1}$ M. Bellafiore, ${ }^{1}$ S. David, ${ }^{1}$ F. Rappa, ${ }^{1}$ M. Marasà, ${ }^{1}$ G. Peri, ${ }^{1}$ F. Farina, ${ }^{1}$ \\ A.M. Czarnecka, ${ }^{2}$ E. Conway de Macario, ${ }^{3}$ A.J.L. Macario, ${ }^{3}$ G. Zummo, ${ }^{1}$ F. Cappello ${ }^{1}$
}

${ }^{1}$ Human Anatomy Section, Department of Experimental Medicine, University of Palermo, Palermo, Italy; ${ }^{2}$ Department of Genetics, University of Warsaw, Warszawa, Poland; ${ }^{3}$ University of Maryland Biotechnology Institute, Center of Marine Biotechnology, Baltimore, MD, USA

(C)2008 European Journal of Histochemistry

Hsp60, a mitochondrial chaperonin highly conserved during evolution, has been found elevated in the cytosol of cancer cells, both in vivo and in vitro, but its role in determining apoptosis during oxidative stress (OS) has not yet been fully elucidated. The aim of the present work was to study the effects of OS on Hsp60 levels and its interactions with procaspase-3 (p-C3) and p53 in tumor cells. NCl-H292 (mucoepidermoid carcinoma) cells were exposed to various concentrations of hydrogen peroxide $\left(\mathrm{H}_{2} \mathrm{O}_{2}\right)$ for 24 hours. Cell viability was determined by Trypan blue and MTT assays. DNA damage was assessed by the Comet assay, and apoptosis was measured by the AnnexinV cytofluorimetric test. Exposure to increasing concentrations of $\mathrm{H}_{2} \mathrm{O}_{2}$ resulted in a reduction of cell viability, DNA damage, and early apoptotic phenomena. Hsp60, p-C3, p53, and p21 were assessed by Western blotting and immunocytochemistry before and after OS. Hsp60 and p-C3 were present before and after OS induction. Immunoprecipitation experiments showed an Hsp60/p-C3 complex before OS that persisted after it, while an Hsp60/p53 complex was not detected in either condition. The presence of wild type (wt) p53 was confirmed by RT-PCR, and p21 detection suggested p53 activation after OS. We postulate that, although OS may induce early apoptosis in $\mathrm{NCl}-\mathrm{H} 292$ cells, Hsp60 exerts an anti-apoptotic effect in these cells and, by extension, it may do so in other cancer cells.

Key words: Chaperonin, Hsp60, Cpn60, procaspase-3 caspase-3, DNA damage, p53, apoptosis.

Correspondence: Francesco Cappello,

Human Anatomy Section, Department of Experimental Medicine, University of Palermo,

via del Vespro 129, 90127 Palermo, Italy

Tel.: +39.091 .6553518 .

Fax: +39.091 .6553580$

E-mail: francapp@hotmail.com

Paper accepted on September 9, 2008

European Journal of Histochemistry

2008; vol. 52 issue 4 (October-December):221-228 $\square$ eat shock proteins (Hsps) perform critical functions in maintaining protein homeostasis under physiological and stressful conditions (Ritossa, 1996; Walter and Buchner, 2002). Hsp60, a Group I chaperonin, is found in bacteria and eukaryotic organelles, whereas Group II chaperonins occur in Archea and eukaryotic cytosol, typically forming double-ringed structures (Macario et al., 1999; 2004). At least nine genes have been identified for Group II but only one for Group I proteins in humans (Kubota et al., 1995; Hansen et al., 2003).

Hsp60 (the mitochondrial version of it is also called Cpn60) forms a complex with its co-chaperonin HsplO to fold and assemble proteins in the presence of ATP (Nielsen et al., 1999). Hsp60, including probably the mitochondrial Cpn60, can be elevated in a number of human tumors (Czarnecka et al., 2006; Cappello et al., 2007; 2008) and in the extracellular milieu, which can cause activation of an antitumor immune response (Calderwood et al., 2007). Whether and when mitochondrial and cytosolic Hsp60 have pro- or anti- apoptotic roles is still unclear, since there is evidence supporting both possibilities (Samali et al., 1999; Xanthoudakis et al., 1999; Gupta et al., 2005; Veereshwarayya et al., 2006; Chandra et al., 2007). In addition, it was demonstrated that increased expression of Hsp60, Hsp70, and Hsp90 interferes with mitochondrial apoptotic pathways in human neuroblastoma cells (Veereshwarayya et al., 2006).

Reactive oxygen species (ROS) have been linked to cellular damage in various pathophysiological disorders, such as cancer. Free radicals are recognized as important players in the induction of apoptotic cell death and necrosis. A well documented cause of apoptosis after oxidative stress (OS) is DNA damage. Oxygen radicals are powerful DNA 
damaging agents. ROS cause strand breaks, alterations in guanine and thymine bases, and sister chromatid exchanges (Wiseman and Halliwell, 1996). Repair of DNA damage is mediated by p53 (Jackson et al., 2002; Lane and Crawford, 1979). The mechanism by which p53 detects damage and signals the induction of apoptosis is not yet fully understood, but it has been shown that mitochondria are involved (Ryan et al., 2001; Fischer et al., 2004). It has also been demonstrated that p53 may shift cell cycle towards apoptosis via an alternative pathway, and that p53 directly translocates to mitochondria in response to death signal stimuli, e.g., hypoxia (Marchenko et al., 2000). Moreover, the localization of p53 to mitochondria precedes the release of cytochrome $c$ and procaspase-3 ( $p$ C3) activation (Sansome et al., 2001).

In our work, we investigated the effects of OS on Hsp60 levels and on its molecular interactions with p-C3 and p53 in a tumor cell line, which was chosen because at basal (unstressed) conditions Hsp60 is present at high levels in the cytoplasm and p53 is present in the wild-type form.

\section{Materials and Methods}

\section{Cell culture and treatment protocols}

NCI-H292 cells were grown as a monolayer culture with Roswell Park Memorial Institute medium (RPMI-1640 medium, Sigma-Aldrich), supplemented with $10 \%$ fetal calf serum (FCS), penicillin (100 U/ $\mathrm{mL})$, streptomycin (100 $\mu \mathrm{g} / \mathrm{mL})$ and amphotericin $\mathrm{B}(0.25 \mu \mathrm{g} / \mathrm{mL})$, at $37^{\circ} \mathrm{C}$ in a $5 \%$ $\mathrm{CO}_{2}$ atmosphere. Adherent cells were harvested by trypsin digestion in $\mathrm{Ca}^{2+} / \mathrm{Mg}^{2+}$-free Hanks' balanced salt solution, washed with phosphate-buffered saline (PBS) and resuspended in supplemented RPMI medium. Cells were seeded at $1 \times 10^{4}$ cells $/ \mathrm{mL}$ in 24-well plates. After cells reached approximately $70 \%$ of confluence, they were rendered quiescent with $1 \%$ FCS medium for $24 \mathrm{~h}$ and then treated with $\mathrm{H}_{2} \mathrm{O}_{2}$ at various concentrations ( 0 to $600 \mu \mathrm{M})$ for $24 \mathrm{~h}$ at $37^{\circ} \mathrm{C}$, according to the protocol used by Merendino et al. (2006).

\section{Trypan blue dye exclusion and MTT assays}

Cell viability was assessed by Trypan blue dye exclusion (TB) and MTT (3-(4,5-dimethylthiazol2-yl)-2,5-diphenyl tetrazolium bromide) assays (Strober, 2001; Hayon et al., 2003). For the TB assay, $10 \mu \mathrm{L}$ of the cell suspension was mixed with $10 \mu \mathrm{L}$ of $\mathrm{TB}$, aliquots were placed on a counter chamber, and cells were differentially counted under the microscope. For the MTT assay, a $20 \mu \mathrm{L}$ solution of $5 \mathrm{mg} / \mathrm{mL}$ MTT dissolved in PBS was added to the cells that were cultured for $5 \mathrm{~h}$ at $37^{\circ} \mathrm{C}$. The medium was removed, $200 \mu \mathrm{L}$ of DMSO added and crystals dissolved. Absorbance was measured at $550 \mathrm{~nm}$ with a plate reader.

\section{Comet assay}

The single-cell gel electrophoresis or "Comet assay" was performed according to the original protocols of Singh et al. (1988). Following treatments, the medium was removed. The cells were washed with ice-cold PBS and trypsinized with 1\% trypsin in $\mathrm{Ca}^{2+} / \mathrm{Mg}^{2+}$-free Hanks' balanced salt solution. After 3 min at $37^{\circ} \mathrm{C}$, complete medium was added and the cells gently resuspended. Slides were prepared with $1 \%$ normal melting agarose (NMA). Approximately 10,000 cells were mixed with $85 \mu \mathrm{L}$ of low melting point $0.7 \%$ agarose ( LMA) agarose at $37 \%$ and applied to the prepared slides. The slides were immersed in a lysing solution made of $2.5 \mathrm{M} \mathrm{NaCl}, 0.1 \mathrm{M} \mathrm{Na} 2 \mathrm{EDTA}, 10^{-2} \mathrm{M}$ Tris- $\mathrm{HCl}, 1 \%$ sodium sarcosinate, $\mathrm{pH} 10$, with $1 \%$ Triton $\mathrm{X}-100$ and $10 \%$ DMSO added just before use. The cells were kept at $4^{\circ} \mathrm{C}$, in the dark, for at least $\mathrm{lh}$ for lysing and promoting DNA unwinding. The slides were removed from the lysing solution, drained and placed on a horizontal gel electrophoresis unit, side by side. The tank was filled with chilled fresh alkaline solution $\left(10^{-3} \mathrm{M}\right.$ Na2 EDTA, $\left.0.3 \mathrm{M} \mathrm{NaOH}\right)$ at $4^{\circ} \mathrm{C}$ and $\mathrm{pH}$ 12.8. Before electrophoresis, the slides were left in the solution for 20 min to allow for completion of DNA unwinding. Electrophoresis was conducted in alkaline buffer at $4^{\circ} \mathrm{C}$ for $20 \mathrm{~min}$, at $25 \mathrm{~V}$ and $300 \mathrm{~mA}$. After electrophoresis, slides were gently washed in a neutralization buffer $(0.4 \mathrm{M}$ Tris- $\mathrm{HCl}, \mathrm{pH}$ 7.5) to remove alkali and detergent, and stained with $50 \mu \mathrm{L}$ DAPI $(5 \mu \mathrm{g} / \mathrm{mL})$ in Vectashield (mounting medium for fluorescence $\mathrm{H}$ 1000, Vector Laboratories, USA). Microscope slides were viewed using a Leica fluorescence microscope. Image analysis was performing using the TriTek CometScore Freeware Software (http://www.tritekcorp.com/products_cometscore.php). The tail-length was measured in 50 comets per slide. Scoring was done with a double blind approach. Each slide was coded and measurement of DNA damage was performed by an observer who 
was unaware of the treatment group from which the sample was derived. Statistical analysis was performed by ANOVA test; a $p<0.05$ was considered as significant.

\section{Determination of apoptosis by flow cytometry}

Apoptosis was measured according to the technique of Vermes et al. (1995); AnnexinV (AxV) was used to detect phosphatidylserine externalisation on the outer leaflet of the plasma membrane of apoptotic cells. NCI-H292 cells were treated with $200 \mu \mathrm{M}$ and $400 \mu \mathrm{M}$ of $\mathrm{H} 202$ for $24 \mathrm{~h}$. Adherent cells were harvested by trypsin digestion in $\mathrm{Ca}^{2+} / \mathrm{Mg}^{2+}$-free Hanks' balanced salt solution. After washing twice in cold PBS, the cells were resuspended at a density of $1 \times 10^{5}$ cells $/ 100 \mu \mathrm{L}$ of binding buffer (10 mM HEPES pH 7.4, $140 \mathrm{mM} \mathrm{NaCl,}$ $\left.2.5 \mathrm{mM} \mathrm{CaCl}_{2}\right)$ in $5 \mathrm{ml}$ propylene FACS tubes. AxVFITC $(1 \mu \mathrm{g} / \mathrm{mL})$ and Propidium Iodide (PI) (2.5 $\mu \mathrm{g} / \mathrm{mL}$ ) were added to the tubes and incubated in the dark for $15 \mathrm{~min}$, and then $400 \mu \mathrm{L}$ of cold binding buffer was added and the cells were analysed using a FACScan flow cytometer. The degree of early apoptosis was expressed as the number of $\mathrm{Ax} \mathrm{V}^{+} / \mathrm{PI}^{-}$cells shown as a percentage of total cells. The late apoptotic cells were characterised as $\mathrm{AxV}^{+} / \mathrm{PI}^{+}$, and necrotic cells as $\mathrm{PI}^{+}$. Experiments were performed in quintuplicate. Statistical analysis was performed by ANOVA test; a $p<0.05$ was considered as significant.

\section{Preparation of total cell lysates and protein assays}

The harvested cells were treated with $0.25 \%$ trypsin and $1 \mathrm{mM}$ of EDTA and centrifuged at $222 x$ g. Pellets were washed in PBS two times. Subsequently, the cells were resuspended in lysis buffer containing $50 \mathrm{mM}$ Tris/ $\mathrm{HCl}, 150 \mathrm{mM} \mathrm{NaCl}$, $1 \% \mathrm{NP}-40,1 \mathrm{mM}$ EGTA and protease inhibitors (1 mM AEBSF, $1 \mu \mathrm{M}$ Aprotinin, $50 \mu \mathrm{M}$ Bestatin, $15 \mu \mathrm{M}$ E-64, $20 \mu \mathrm{M}$ Leupeptin, $10 \mu \mathrm{M}$ Pepstatin A). Cell lysates were then incubated for $30 \mathrm{~min}$ on ice and then sonicated for 3-5 seconds on ice and then centrifuged at $14,000 \times \mathrm{g}$ for 10 minutes. Total proteins were detected using the Bio-Rad Dc Protein Assay kit. Protein concentrations were determined by comparing the absorbance value with a known value based on a calibration curve, for bovine serum albumin (BSA). The samples were mixed with vortex and incubated for 15 minutes in the dark. The absorbance was measured at $750 \mathrm{~nm}$.

\section{Polyacrylamide gel electrophoresis and Western blot analyses}

Proteins were separated by electrophoresis on denaturing $12 \%$ polyacrylamide gel (SDS-PAGE). Equal amounts of proteins $(25 \mu \mathrm{g})$ were loaded on to each lane and transferred to PVDF membranes ( $\mathrm{HY}$ Bond-P Amersham Biosciences). The specific binding of antibodies was detected using $\mathrm{ECL}^{\oplus}$ (Amersham Biosciences) and mouse monoclonal antibodies made against human Hsp60 (clone LKI, Sigma, 1:1000), human procaspase-3 (clone E-8, Santa Cruz, 1:1000), human p53 (clone D0-7, Dako, 1:500), or human p21(clone 187, Santa Cruz, 1:1000). Experiments were performed in triplicate.

\section{Immunocytochemistry}

Cells for immunocytochemistry were fixed in methanol. Immunostaining by the streptavidinbiotin complex method (LSAB2 Kit peroxidase, DAKO) was performed using the same mouse primary monoclonal antibodies described above, at the following dilutions: anti-Hsp60 (clone LKI, Sigma, 1:300), anti-human procaspase-3 (clone E-8, Santa Cruz, 1:100), anti-human p53 (clone D0-7, Dako, 1:100), and anti-human p21(clone 187, Santa Cruz, 1:100). Experiments were performed in triplicate.

\section{Immunoprecipitation}

Immunoprecipitation to detect protein complexes (i.e., proteins co-precipitating together) was performed with $5 \mu \mathrm{g}$ of primary antibody per $1 \mathrm{~mL}$ of total cell lysate, incubated overnight at $4^{\circ} \mathrm{C}$ with gentle rotation. The primary mouse monoclonal antibodies used were the same as those described above. Antibody/protein complexes were immunoprecipitated with antibodies linked to sepharose $A$ beads 4 fast few ${ }^{\circledast}$ (Amersham Biosciences). Nonspecifically bound proteins were removed by repeatedly washing with isotonic lysis buffer. Immunoprecipitated proteins were resolved by SDS-PAGE. Experiments were performed in triplicate.

\section{RNA extraction}

Total cellular RNA was extracted from cells at $70 \%$ confluence that had been treated with $\mathrm{H}_{2} \mathrm{O}_{2}$ at $200 \mu \mathrm{M}$ or $400 \mu \mathrm{M}$ concentrations for $24 \mathrm{~h}$. Total cellular RNA was extracted and isolated by using a kit based on the disruptive and protective proper- 
ties of Guanidinium Thiocyanate followed by selective precipitation with Lithium Chloride and Caesium Trifluoroacetate (QuickPrep Total RNA Extraction Kit, Amersham Biosciences). The yield of RNA was quantified spectrophotometrically by measuring absorption at $260 \mathrm{~nm}$.

\section{RT-PCR}

RT-PCR was conducted in a two-step reaction (reverse transcription, followed by $P C R$ ) by using Ready-to-Go RT-PCR Beads (Amersham Biosciences). In the first step, $1 \mu \mathrm{g}$ of total RNA was primed with a random primer. cDNA was polymerised at $42^{\circ} \mathrm{C}$ for $30 \mathrm{~min}$ and the double-stranded RNA:cDNA heteroduplex was denatured at $95^{\circ} \mathrm{C}$ for 5 min to allow the cDNA to be used as a template for polymerisation in the second step. PCR amplification of cDNA was performed adding to the reaction specific primers for p53. The forward primer sequence was 5'- GTT CCG AGA GCT GAA TGA GG - $3^{\prime}$ and the reverse primer was $5^{\prime}$ CTG AGT CAG GCC CTT CTG TC - 3'. The product of PCR was a fragment of 158 bp. mRNA was normalized to the amount of beta-actin mRNA, which was used as a basal, housekeeping gene product for each experimental condition. The $\mathrm{PRC}$ reactions were cycled at $95^{\circ} \mathrm{C}$ for $30 \mathrm{~s}, 60^{\circ} \mathrm{C}$ for $60 \mathrm{~s}, 72^{\circ} \mathrm{C}$ for $60 \mathrm{~s}$, with a final extension at $72^{\circ} \mathrm{C}$ for 5 min. RT-PCR products were separated and visualized on $2 \%$ agarose gel with the ethidium bromide stain. Experiments were performed in triplicate.

\section{Results}

\section{Inhibition of growth in cells exposed to $\mathrm{H}_{2} \mathrm{O}_{2}$}

To determine whether $\mathrm{H}_{2} \mathrm{O}_{2}$ induced cell-death in our system, we cultured NCI-H292 cells in RPMI supplemented with varying concentrations of $\mathrm{H}_{2} \mathrm{O}_{2}$ ( 0 to $600 \mu \mathrm{M}$ ). After $24 \mathrm{~h}$, exposure to increasing concentrations of $\mathrm{H}_{2} \mathrm{O}_{2}$ determined a dose-dependent reduction of cell viability as shown by MTT and TB assays (Figure $1 \mathrm{~A}$ ).

\section{DNA damage}

DNA damage in NCI-H292 cells was determined by the Comet assay after a Ih treatment with $200 \mu \mathrm{M}$ or $400 \mu \mathrm{M}$ of $\mathrm{H}_{2} \mathrm{O}_{2}$. After treatments, the cells showed typical comets, which were absent in the cells that had not been treated with $\mathrm{H}_{2} \mathrm{O}_{2}$ (Figure $1 \mathrm{~B}$, insets). We used the TriTek Comet
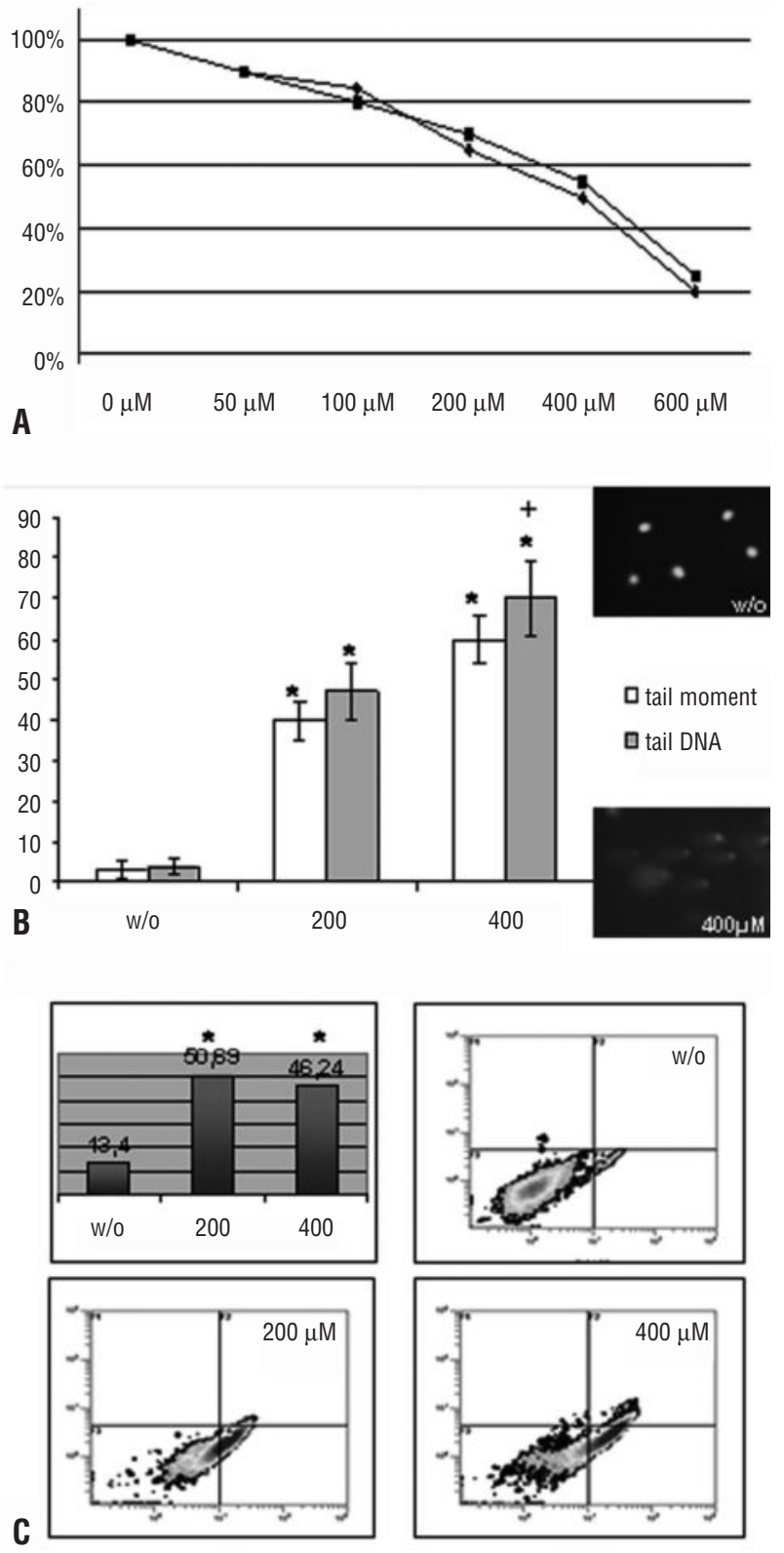

Figure 1. (A) NCl-H292 cell viability at various $\mathrm{H}_{2} \mathrm{O}_{2}$ concentrations for $\mathbf{2 4}$ hours. Lines indicate results from trypan blue (TB) $(O)$ and MTT $(\square)$ cell viability tests. Vertical axis, cell viability index; horizontal axis, concentration of $\mathrm{H}_{2} \mathrm{O}_{2}$ in $\mu \mathrm{M}$ (w/o indicates untreated cells). Both TB and MTT tests gave analogous results, demonstrating a dose-dependent decrease of cell viability. (B) Induction of DNA damage in NCI-H292 cells by $\mathrm{H}_{2} \mathrm{O}_{2}$ treatment: evaluation by comet assay. The bar graphs show DNA damage percentages obtained by software TriTek Comet Score (see text for further details); * represents statistically significant difference $(p<0.05)$ when datasets (tail moment and tail DNA) were compared between treated and untreated cells; +represents significance $(p<0.05)$ when datasets (tail moment and tail DNA) were compared between $200 \mu \mathrm{M}$ and $400 \mu \mathrm{M}$. Insets show untreated cells ( $w / 0$, upper right) and cells treated with $400 \mu \mathrm{M}$ of $\mathrm{H}_{2} \mathrm{O}_{2}$ (lower right). Magnification 100X. C) Evaluation of apoptotic phenomena after $\mathrm{H}_{2} \mathrm{O}_{2}$ treatments by flow cytometry. The bar graphs (upper left) show the percentages of $\mathrm{NCl}-\mathrm{H} 292$ apoptotic cells in untreated $(\mathrm{W} / 0)$ and treated $\left(200 \mu \mathrm{M}\right.$ and $400 \mu \mathrm{M}$ of $\left.\mathrm{H}_{2} \mathrm{O}_{2}\right)$ cells. The percentage of cells in early apoptosis increased significantly $\left({ }^{*}\right)$ at both $200 \mu \mathrm{M}$ and $400 \mu \mathrm{M}$ concentrations of $\mathrm{H}_{2} \mathrm{O}_{2}$ (see text for further details). 
score to analyze both tail moment and tail DNA, to assess DNA damage, and found a significant ( $p<0.05$ ) increment of both values after $\mathrm{H}_{2} \mathrm{O}_{2}$ treatment (Figure 1 B).

\section{Induction of apoptosis in $\mathrm{NCl}-\mathrm{H} 292$ cells by $\mathrm{H}_{2} \mathrm{O}_{2}$ : evaluation by flow cytometry}

To verify whether $\mathrm{H}_{2} \mathrm{O}_{2}$ was able to trigger apoptosis in the NCI-H292 cells, we evaluated the presence of phosphatidylserine on their surface using FITC-conjugated AxV. After $24 \mathrm{~h}$ incubation with $\mathrm{H}_{2} \mathrm{O}_{2}$, the number of $\mathrm{PI}^{-}$and $\mathrm{AxV}^{+}$cells significantly increased when NCI-H292 cells were treated with $200 \mu \mathrm{M}$ or $400 \mu \mathrm{M}$ of $\mathrm{H}_{2} \mathrm{O}_{2}$. In untreated cells, the percentage of cells in early apoptosis was $3.57 \pm 0.81 \%$; when the cells were treated with 200 $\mu \mathrm{M}$ or $400 \mu \mathrm{M}$ of $\mathrm{H}_{2} \mathrm{O}_{2}$, the percentage of cells in early apoptosis increased significantly, to $50.69 \pm 2.098 \% \quad(p<0.01)$ and $46.24 \pm 2.90 \%$ $(p<0.02)$, respectively (Figure $1 C$ ).

\section{Expression of Hsp60/p53/p21/p-C3}

$\mathrm{Hsp} 60$ and $\mathrm{p}-\mathrm{C} 3$ were expressed before and after $\mathrm{H}_{2} \mathrm{O}_{2}$ treatments according to Western blotting and immunocytochemistry data (Figure 2); also p53 did not change after $\mathrm{H}_{2} \mathrm{O}_{2}$ treatments: it was expressed at very low levels in untreated cells as well as in cells exposed to $200 \mu \mathrm{M}$ or $400 \mu \mathrm{M}$ of $\mathrm{H}_{2} \mathrm{O}_{2}$, (not
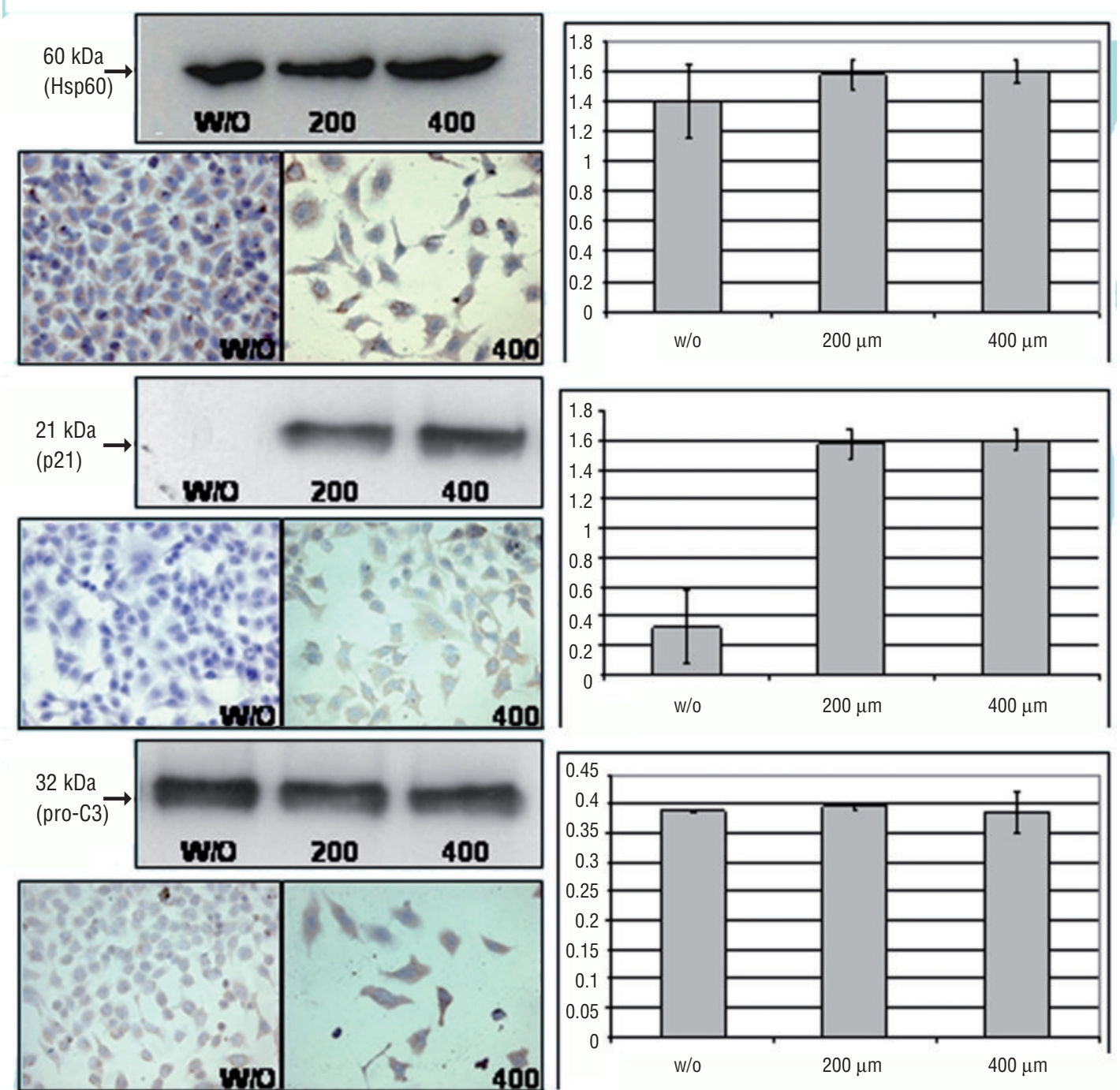

Figure 2. On the left side are shown representative Western blottings and immunocytochemical (original magnifications: 400x) pictures for Hsp60 (top), p21 (middle), and pro-C3 (bottom). W/0: untreated cells; 200: cells treated with $200 \mu \mathrm{M}$ of $\mathrm{H}_{2} \mathrm{O}_{2}$; 400 : cells treated with $400 \mu \mathrm{M}$ of $\mathrm{H}_{2} \mathrm{O}_{2}$; quantification of protein levels was obtained normalising for $\beta$-actin and it is showed on the right side of the panel. Hsp60 and pro-C3 were present in untreated and treated cells, while p21 was detectable only after treatment; p53 was undetectable by neither Western blotting nor immunocytochemistry under all conditions tested (not shown), but it was detectable by RT-PCR (Figure 3 ). 
shown); because of these results, we decided to perform RT-PCR experiments (see below) to verify p53 presence before and after treatments. p21 was detected after $\mathrm{H}_{2} \mathrm{O}_{2}$ stimulations, as shown by both immunocytochemistry and western blotting (Figure 2).

\section{RT-PCR and immunoprecipitation analyses}

Expression of p53 was demonstrated by RT-PCR in all experimental conditions (untreated and treated cells) tested (Figure 3 A, B). Co-immunoprecipitation studies performed on total cell lysates showed that $\mathrm{p}-\mathrm{C} 3$ co-precipitated with $\mathrm{Hsp} 60$ both in untreated and treated cells (Figure $3 \mathrm{C}$ ). In contrast, p53 did not co-precipitate with Hsp60 under any of the conditions tested (data not shown).

\section{Discussion}

Hsps are an evolutionary conserved family of functionally related proteins, and many of them are molecular chaperones (Ellis, 1990; Ritossa, 1996; Walter and Buchner, 2002; Macario et al., 1999; 2004; Young et al., 2004). These are capable of recognizing and binding substrate proteins in an unstable or inactive state and assisting them in folding or refolding to achieve a native conformation. Hsps form an ancient anti-stress, defence system in all living organisms on earth, mediating a wide range of intracellular activities, and their expression can be induced by a variety of stressors including apoptotic stimuli. Hsp60 is a chaperonin localized to the inner mitochondrial membrane and
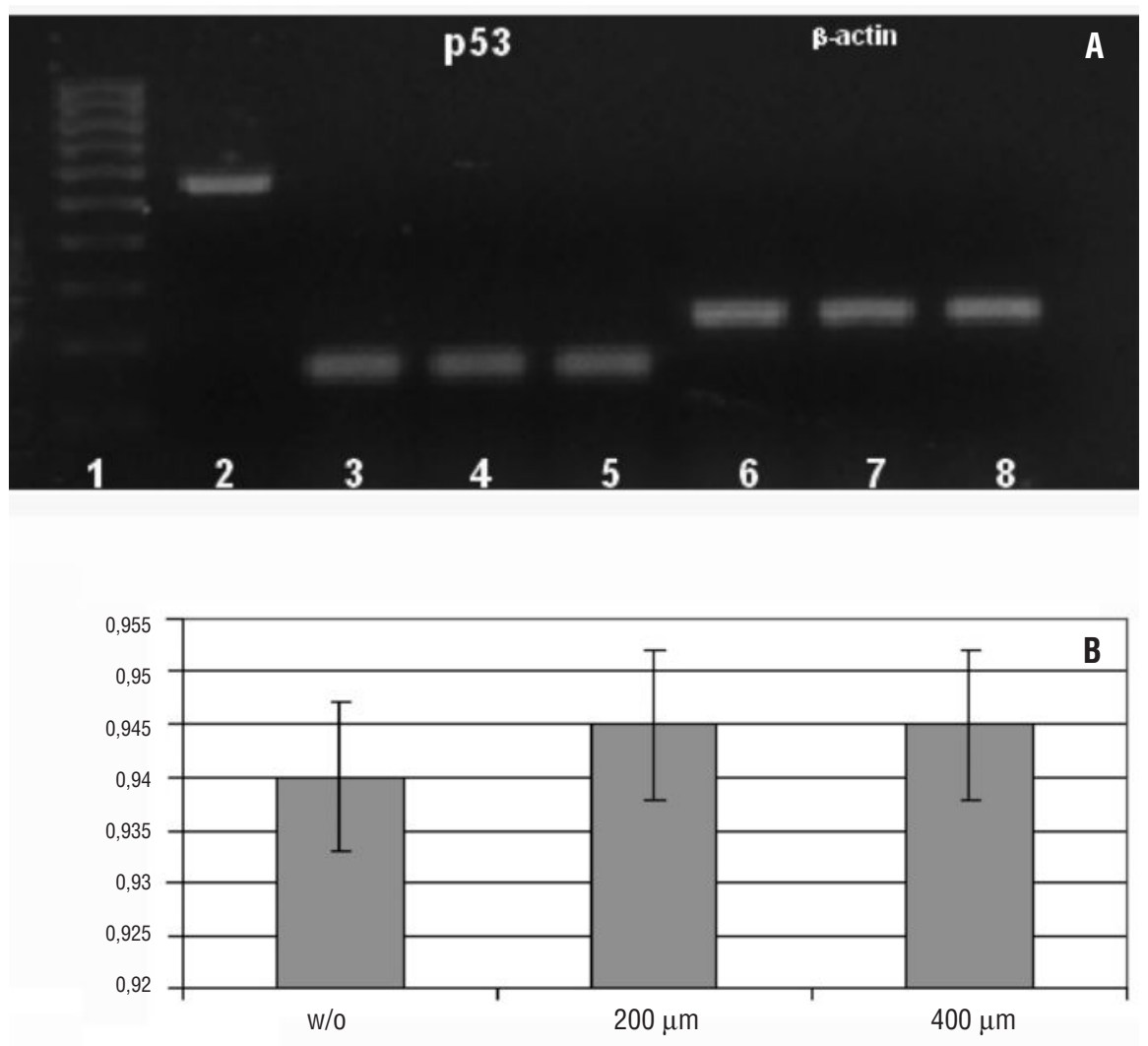

Figure 3. (A) Detection of p53 mRNA by RT-PCR. Lanes: 1, 1001,000 bp-size marker; 2 , internal positive control; 3 , p53 in untreated cells; $4, \mathrm{p} 53$ in cells treated with $200 \mu \mathrm{M}$ of H202; 5, p53 in cells treated with $400 \mu \mathrm{M}$ of $\mathrm{H}_{2} \mathrm{O}_{2}$; $6, \beta$-actin in untreated cells; $7, \beta$ actin in cells treated with $200 \mu \mathrm{M}$ of $\mathrm{H2O2} ; 8, \beta$-actin in cells treated with $400 \mu \mathrm{M}$ of $\mathrm{H}_{2} \mathrm{O}_{2}$. (B) The bar graphs show quantification of p53 mRNA levels normalised for $\beta$ actin. (C) Co-immunoprecipitation tests in total cell lysates for Hsp60/p53 (left subpanel) and Hsp60/procaspase-3 (right subpanel) complexes. Lanes from left to right in each subpanel: 1 , untreated cells; 2 , cells treated with $200 \mu \mathrm{M}$ of $\mathrm{H}_{2} \mathrm{O}_{2} ; 3$, cells treated with $400 \mu \mathrm{M}$ of $\mathrm{H}_{2} \mathrm{O}_{2}$. Immunoprecipitation was carried out using antibodies against p53 followed by Western blotting with antibodies to Hsp60 (left subpanel), or using antibodies against procaspase-3 followed by Western blotting with antibodies to Hsp60 (right subpanel). The Hsp60/procaspase-3 complex was detected under all conditions tested while no Hsp60/p53 complex was observed.

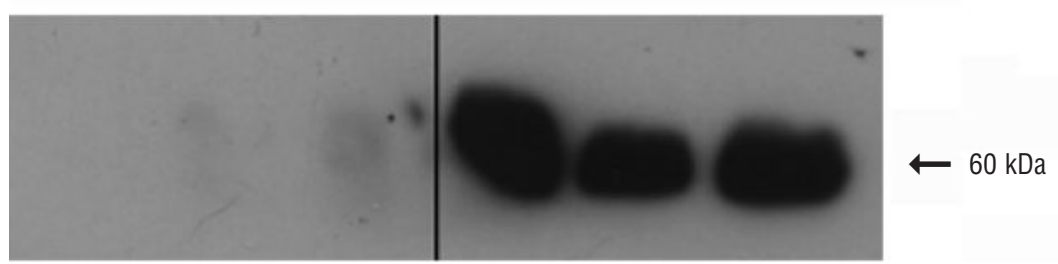


matrix and, less frequently, to extramitochondrial sites (Soltys and Gupta, 1996, 1997, 1999; Cappello et al., 2008). Hsp60 is constitutively expressed under normal conditions, but its levels can increase (as determined by immunohistochemical methods for example) in pre-neoplastic lesions (Cappello et al., 2002, 2003a, 2003b; Fan et al., 2006) and in many advanced cancers (Schneider et al., 1999; Cappello et al., 2005; Urushibara et al., 2007). The main function of the mitochondrial Hsp60 is considered to be assistance in the folding and degradation of mitochondrial proteins (Garrido et al., 2001; Levy-Rimler et al., 2002; Fersht and Daggett, 2002; Parcellier et al., 2003). The involvement of Hsp6O in the process of apoptosis and tumorigenesis is still under debate. In a recent work, Chandra et al. (2007) showed that Hsp60, when it accumulates in the cytosol of tumor cells with significant mitochondrial release, possesses a pro-apoptotic function. In contrast, when Hsp60 accumulates in cytosol without mitochondrial release, it exerts an anti-apoptotic effect. The prodeath role of Hsp60 seemed to involve caspase-3 maturation but when Hsp60 played a pro-survival role, it did not associate with active caspase-3 (Chandra et al., 2007).

The aim of the present work was to explore whether Hsp60 interacts with $\mathrm{p}-\mathrm{C} 3$ and $\mathrm{p5} 3$ in a cancer model system submitted to OS, a type of stress known to occur in many tumors, causing not only nuclear but also mitochondrial and cytosolic damage (Renis et al., 1996; Grasso et al., 2003). For this purpose, the tumor cell line NCI-H292 was chosen as a model system and studied before and after $\mathrm{OS}$ induction with $\mathrm{H}_{2} \mathrm{O}_{2}$.

We found that $\mathrm{Hsp} 60$ is present in untreated and treated NCI-H292 cells, as shown by immunocytochemistry and Western blotting. These results, together with the demonstration of an $\mathrm{Hsp} 60 / \mathrm{p}-\mathrm{C}_{3}$ complex before and after OS, support the hypothesis that Hsp60 has an anti-apoptotic role in NCI$\mathrm{H} 292$ cells. The levels of p53 were very low in Western blotting tests, below a detectable threshold by immunocytochemistry; these results are typically obtained when p53 is in the wild-type form, since it has a short half-life. However, p53 was clearly demonstrated by RT-PCR, which together with the demonstration (by immunocytochemistry and Western blotting) of p21 expression after OS, strongly supports the notion that p53 activation had occurred after OS. Contrary to our expectation, we did not find an Hsp60/p53 complex neither before nor after OS, disproving our initial hypothesis that these molecules could interact in our model system.

In conclusion, our experiments show that after an OS that causes nuclear damage and activation of p53, the Hsp60/p-C3 complex persists and the latter can have an anti-apoptotic effect. By contrast, no Hsp60/p53 complex was present in our model. Further in vitro experiments are in progress to test this hypothesis, which, if confirmed, would provide a basis for using $\mathrm{Hsp60}$ as a target for antitumoral therapy (Cappello et al., 2007; 2008).

\section{Acknowledgements}

This work was supported by Funds "MIUR ex 60\%" to Francesco Cappello, Giovanni Peri, Felicia Farina and Giovanni Zummo.

\section{References}

Calderwood SK, Mambula SS, Gray PJ Jr. Extracellular heat shock proteins in cell signaling and immunity. Ann N Y Acad Sci 2007; 1113:28-39.

Cappello F, Bellafiore M, Palma A, Marciano V, Martorana G, Belfiore $P$, et al. Expression of $60-k D$ heat shock protein increases during carcinogenesis in the uterine exocervix. Pathobiology 2002;70:838

Cappello F, Bellafiore M, Palma A, David S, Marcianò V, Bartolotta T, et al. 60KDa chaperonin (HSP60) is over-expressed during colorectal carcinogenesis. Eur J Histochem 2003(a);47:105-10.

Cappello F, Rappa F, David S, Anzalone R, Zummo G. Immunohistochemical evaluation of PCNA, p53, HSP60, HSP10 and MUC2 presence and expression in prostate carcinogenesis. Anticancer Res 2003(b);23:1325-31.

Cappello F, David S, Rappa F, Bucchieri F, Marasà L, Bartolotta TE, et al. The expression of HSP60 and HSP10 in large bowel carcinomas with lymph node metastase. BMC Cancer 2005; 5:139.

Cappello F, Czarnecka AM, La Rocca G, Di Stefano A, Zummo G, Macario AJL. Hsp60 and Hspl0 as antitumor molecular agents. Cancer Biol Ther 2007;6:487-9.

Cappello F, Conway de Macario E, Marasà L, Zummo G, Macario AJL. Hsp60 expression, new locations, functions, and perspectives for cancer diagnosis and therapy. Cancer Biol Ther 2008;7:801-9.

Chandra D, Choy G, Tang DG. Cytosolic accumulation of HSP60 during apoptosis with or without apparent mitochondrial release: evidence that its pro-apoptotic or pro-survival functions involve differential interactions with caspase-3. J Biol Chem 2007;282:31289301.

Czarnecka AM, Campanella C, Zummo G, Cappello F. Mitochondrial chaperones in cancer: from molecular biology to clinical diagnostics. Cancer Biol Ther 2006;5:714-20.

Ellis RJ. The molecular chaperone concept. Semin Cell Biol 1990;1:19.

Fan GK, Chen J, Ping F, Geng Y. Immunohistochemical analysis of P57(kip2), p53 and hsp60 expressions in premalignant and malignant oral tissues. Oral Oncol 2006;42:147-53.

Fersht AR, Daggett V. Protein folding and unfolding at atomic resolution. Cell 2002;108:573-82.

Fischer OM, Hart S, Gschwind A, Prenzel N, Ullrich A. Oxidative and osmotic stress signaling in tumor cells is mediated by ADAM pro- 
teases and heparin-binding epidermal growth factor. Mol Cel Biol 2004;24:5172-83.

Garrido C, Gurbuxani S, Ravagnan L, Kroemer G. Heat shock proteins: endogenous modulators of apoptotic cell death. Biochem Biophys Res Com 2001;286:433-42.

Grasso S, Scifo C, Cardile V, Gulino R, Renis M. Adaptive responses to the stress induced by hyperthermia or hydrogen peroxide in human fibroblasts. Exp Biol Med 2003;228:491-8.

Gupta S, Knowlton AA. HSP60, Bax, apoptosis and the heart. J Cell Mol Med 2005;9:51-8.

Hansen JJ, Bross P, Westergaard M, Nielsen M N, Eiberg H, Borglum $A D$, et al. Genomic structure of the human mitochondrial chaperonin genes: HSP60 and HSP10 are localised head to head on chromosome 2 separated by a bidirectional promoter. Hum Genet. 2003;112:71-7.

Hayon T, Dvilansky A, Shpilberg 0, Nathan I. Appraisal of the MTTbased assay as a useful tool for predicting drug chemosensitivity in leukemia. Leuk Lymphoma 2003;44:1957-62.

Jackson MJ, Papa S, Bolanos J, Bruckdorfer R, Carlsen H, Elliott RM, et al. Antioxidants, reactive oxygen and nitrogen species, gene induction and mitochondrial function. Mol Asp Med 2002;23:209-85.

Kubota H, Hynes G, Willison $\mathrm{K}$. The chaperonin containing t-complex polypeptide 1 (TCP-1). Multisubunit machinery assisting in protein folding and assembly in the eukaryotic cytosol. Eur J Biochem 1995;230:3-16.

Lane DP, Crawford LV. T antigen is bound to a host protein in SV40transformed cells. Nature 1979; 278:261-3.

Levy-Rimler G, Bell RE, Ben-Tal N, Azem A. Type I chaperonins: not all are created equal. FEBS Lett 2002;529:1-5.

Macario AJL, Lange M, Ahring BK, Conway de Macario E. Stress genes and proteins in the archaea. Microbiol Mol Biol Rev 1999; 63:923-67.

Macario AJL, Malz M, Conway de Macario E. Evolution of assisted protein folding: the distribution of the main chaperoning systems within the phylogenetic domain archaea. Front Biosci 2004; 9:1318-32.

Marchenko ND, Zaika A, Moll UM. Death signal-induced localization of p53 protein to mitochondria. J Biol Chem 2000;275:16202-12.

Merendino AM, Bucchieri F, Gagliardo R, Daryadel A, Pompeo F, Chiappara G, et al. CD40 ligation protects bronchial epithelium against oxidant-induced caspase-independent cell death. Am J Respir Cell Mol Biol 2006;35:155-64.

Nielsen KL, McLennan N, Masters M, Cowan NJ. A single-ring mitochondrial chaperonin (Hsp60-Hsp10) can substitute for GroELGroES in vivo. J Bacteriol 1999; 181:5871-5.

Parcellier A, Gurbuxani S, Schmitt E, Solary E, Garrido C. Heat shock proteins, cellular chaperones that modulate mitochondrial cell death pathways. Biochem Biophys Res Commun 2003;304:505-12.

Renis M, Calabrese V, Russo A, Calderone A, Barcellona ML, Rizza V. Nuclear DNA strand breaks during ethanol-induced oxidative stress in rat brain. FEBS Lett 1996;390:153-6.

Ritossa F. Discovery of the heat shock response. Cell Stress Chaperones 1996;1:97-8.
Ryan KK, Philips AC, Vousden KH. Regulation and function of the p53 tumor supressor protein. Current Opin Cell Biol 2001;13:332-7.

Samali A, Cai J, Zhivotovsky B, Jones DP, Orrenius S. Presence of a pre-apoptotic complex of pro-caspase-3, Hsp60 and Hspl0 in the mitochondrial fraction of Jurkat cells. EMBO J 1999;18:2040-8.

Sansome C, Zaika A, Marchenko ND, Moll UM. Hypoxia death stimulus induces translocation of p53 protein to mitochondria. Detection by immunofluorescence on whole cells. FEBS Lett 2001;488:1105 .

Schneider J, Jiménez E, Marenbach K, Romero H, Marx D, Meden H. Immunohistochemical detection of HSP60-expression in human ovarian cancer. Correlation with survival in a series of 247 patients. Anticancer Res 1999;19:2141-6.

Singh NP, McCoy MT, Tice RR, Schneider EL. A simple technique for quantitation of low levels of DNA damage in individual cells. Exp Cell Res 1988;175:184-91.

Soltys BJ, Gupta RS. Immunoelectron microscopic localization of the $60-\mathrm{kDa}$ heat shock chaperonin protein (HSP60) in mammalian cells. Exp Cell Res 1996;222:16-27.

Soltys BJ, Gupta RS. Cell surface localization of the $60 \mathrm{kDa}$ heat shock chaperonin protein ( $\mathrm{HSP} 60$ ) in mammalian cells. Cell Biol Int 1997;21:315-20.

Soltys BJ, Gupta RS. Mitochondrial-matrix proteins at unexpected locations: are they exported? Trends Biochem Sci 1999;24:174-7.

Strober W. Trypan blue exclusion test of cell viability. Curr Protoc Immunol 2001; Appendix 3:Appendix 3B.

Urushibara M, Kageyama Y, Akashi T, Otsuka Y, Takizawa T, Koike M, et al. HSP60 may predict good pathological response to neoadjuvant chemoradiotherapy in bladder cancer. Jpn J Clin Oncol 2007; 37:56-61.

Vermes I, Haanen C, Steffens-Nakken H, Reutelingsperger C. A novel assay for apoptosis: flow cytometric detection of phosphatidylserine expression on early apoptotic cells using fluorescein labelled Annexin V. J Immunol Methods 1995;184:39-51.

Veereshwarayya V, Kumar P, Rosen KM, Mestril R, Querfurth HW. Differential effects of mitochondrial heat shock protein 60 and related molecular chaperones to prevent intracellular beta-amyloidinduced inhibition of complex IV and limit apoptosis. J Biol Chem 2006;281:29468-78.

Walter S, Buchner J. Molecular chaperones-cellular machines for protein folding. Angew Chem Int Ed Engl 2002;241:1098-113.

Wiseman $H$, Halliwell B. Damage to DNA by reactive oxygen and nitrogen species: role in inflammatory disease and progression to cancer. Biochem J 1996;313:17-29.

Xanthoudakis S, Roy S, Rasper D, Hennessey T, Aubin Y, Cassady R, et al. Hsp60 accelerates the maturation of pro-caspase- 3 by upstream activator proteases during apoptosis. EMBO J 1999;18:2049-56.

Young CJ, Agashe VR, Siegers K, HartI FU. Pathways of chaperonemediated protein folding in the cytosol. Nature $\mathrm{R}$ Mol Cell Biol 2004;5:781-91. 